\title{
IGUALDADE, DISCRIMINAÇÃO E DIREITO DO TRABALHO
}

\author{
EQUAL TREATMENT, DISCRIMINATION AND LABOR LAW
}

Estêvão Mallet*

\begin{abstract}
Resumo:
$\mathrm{O}$ artigo examina as diferentes implicações da igualdade e da discriminação no Direito do Trabalho, abordando a discriminação por motivo de sexo, por motivo de raça, além de outras. Examina, ainda, o problema das ações afirmativas e as dificuldades existentes para a discussão da discriminação em processos judiciais.
\end{abstract}

Palavras-chaves: Direito do Trabalho. Discriminação. Igualdade. Ações afirmativas.

\begin{abstract}
:
The paper examines the various implications of the equal treatment and discrimination in Labor Law, including sex, race and other types of discrimination. It also examines the problem of affirmative action programs and the obstacles in dealing with discrimination in the judicial sphere.
\end{abstract}

Keywords: Labor Law. Discrimination. Equal treatment. Affirmative action programs.

"Dans l'état de nature les homes naissent bien dans l'égalité, mais ils n'y sauroient rester. La société la leur fait perdre, et ils ne redeviennet égaux que par les lois" (Montesquieu, De l'esprit des lois, Livro VIII, Capítulo III)

\section{Introdução}

Existe profunda relação entre a idéia de justiça e a idéia de igualdade. É certo que há vários conceitos de igualdade. Pode-se pensar em igualdade formal ou em igualdade material, bem como em igualdade absoluta ou igualdade relativa. Um dado, porém, é seguro: se não há uma certa igualdade, algum tipo de igualdade pelo menos, não há como falar em justiça. Como anota Friedmann, "equality is a postulate of justice". ${ }^{1}$ Tanto a idéia de justiça está associada à de igualdade que Aristóteles assinalou: "o injusto é desigual, o justo é igual", ${ }^{2}$ o que levou Alf Ross a escrever: "a justiça é igualdade". ${ }^{3}$ Não

\footnotetext{
* Doutor e Livre-Docente em Direito, Professor Associado do Departamento de Direito do Trabalho e da Seguridade Social da Faculdade de Direito da Universidade de São Paulo, Conselheiro da Ordem dos Advogados do Brasil, Secção de São Paulo e advogado.

1 FRIEDMANN, Wolfgang Gaston. Legal theory. 5. ed. London: Stevens \& Sons Limited, 1960. p. 385.

2 ARISTÓTELES. Ética a Nicômaco, v. 6, 1131a.

3 ROSS, Alf. Direito e justiça. São Paulo: Edipro, 2000, § 62, p. 313. Cf., ainda, CURCIO, Carlo. Eguaglianza (dottrine generali). In: ENCICLOPEDIA del Diritto. Varese: Giuffrè, 1965. XIV, p. 513.
} 
por acaso, no dístico inscrito no frontão da Suprema Corte dos Estados Unidos da América lê-se: equal justice under law.

Daí a importância do princípio da igualdade e, ao mesmo tempo, a repulsa provocada pela discriminação. Afinal, o que é a discriminação senão a desigualdade arbitrária, inaceitável e injustificável? Nada mais do que isso. Discriminação supõe desigualdade. Não qualquer desigualdade, como será visto mais adiante, mas a desigualdade ilegítima, intolerável diante das circunstâncias e dos padrões então vigentes. Por isso que, se a justiça se relaciona com a igualdade, e a igualdade repele a discriminação, a discriminação é também a negação da justiça.

\section{A igualdade entre as pessoas ao longo do tempo}

A evolução da humanidade se processa no sentido de redução das desigualdades entre as pessoas. Dá-se tal evolução, portanto, com a gradativa eliminação das discriminações. É evidente que isso ocorre com alguns sobressaltos, com marchas e contramarchas. Mas o sentido é nítido.

Primeiramente há a divisão entre senhores e escravos; entre os que são pessoas e os que nem pessoas são, recebendo o tratamento de objeto de direito. ${ }^{4} \mathrm{O}$ passar do tempo faz com que o elemento humano, comum a todos, prepondere e sejam as pessoas reconhecidas, indistintamente, como sujeitos de direito. Permanecem, todavia, outras distinções, como, por exemplo, a estabelecida entre nobres e servos, aqueles com mais direitos, os últimos com menos direitos. ${ }^{5}$ Já é uma evolução. Mas é, ainda, apenas uma etapa na caminhada.

Com as revoluções liberais do século XVIII e do século XIX o elemento humano, o traço comum já mencionado, ocupa o espaço e as distinções desaparecem. É a consagração da igualdade formal; a abolição de qualquer discriminação em face da lei. Expressiva, a propósito, a referência contida no art. $1^{\circ}$ da Declaração dos Direitos do Homem e do Cidadão: "Les hommes naissent et demeurent libres et égaux en droits".

No Brasil, o princípio da igualdade manifesta-se, de início, no art. 179, § 13, da Constituição de 1824: "A Lei será igual para todos, quer proteja, quer castigue...”. Adquire maior amplitude com a Constituição de 1891, conforme art. 72, § $2^{\circ}$ : "Todos são iguais perante a lei. A República não admite privilégios de nascimento, desconhece foros de nobreza e extingue as ordens honoríficas existentes e todas as suas prerrogativas e regalias, bem como os títulos nobiliárquicos e de conselho". Manteve-se o princípio em todas as Constituições subseqüentes, com modificações de redação apenas. Na Constituição, de

\footnotetext{
4 Por todos, JHERING, Rudolf von. L'esprit du droit romain. Paris: Marescq, 1886. tome deuxième, p. 101 e ss.

5 A propósito, FOIGNET, René. Manuel élémentaire d'histoire du droit français. Paris: Rousseau, 1932. p. 158 e ss.
} 
1988, encontra-se logo no caput, do art. 50: "Todos são iguais perante a lei, sem distinção de qualquer natureza...”.

Para o legislador constituinte, como todas as pessoas naturais são seres humanos, não há mais distinções aceitáveis em face da lei, embora algumas poucas, resquícios de tempos pretéritos, tenham permanecido mais do que deveriam, chegando até a Constituição, de 1988. Somente foram em definitivo revogadas com a edição de outra regra específica, ao lado do princípio geral enunciado pelo caput, do art. $5^{\circ}$. É o caso da distinção entre filhos, que remontava às Ordenações Filipinas, ${ }^{6}$ abolida com o art. 227, $\S 6^{\circ}$, da vigente Constituição: "Os filhos, havidos ou-não da relação do casamento, ou por adoção, terão os mesmos direitos e qualificações, proibidas quaisquer designações discriminatórias relativas à filiação".

Aqui não cabe tratar exaustivamente dessa caminhada no sentido da maior igualdade. É um universo muito vasto, quase inesgotável. O que cabe é considerar como ela se processou no campo do Direito do Trabalho e quais as dificuldades que surgiram e surgem no seu curso.

\section{Igualdade, Direito do Trabalho e discriminação por motivo de sexo}

O preceito que em primeiro lugar chama a atenção em matéria de igualdade, no campo trabalhista, e do qual se podem extrair algumas considerações ricas e interessantes, é o art. $5^{\circ}$ da CLT, introduzido na parte geral, com o claro objetivo de ressaltar a importância da regra posta. Estatui o dispositivo: "Para trabalho de igual valor corresponderá igual salário, sem distinção de sexo". Ao largo das diferentes implicações da regra, há nela pelo menos dois pontos dignos de nota.

De uma parte, é significativa a referência do legislador à igualdade apenas no plano remuneratório. Importante parece ser tão-só a igualdade de remuneração. Os outros aspectos do contrato de trabalho, inclusive o tratamento dispensado a cada empregado, são deixados de lado, em clara mostra da concepção patrimonialista que inspirou a CLT e que ainda impregna o Direito do Trabalho brasileiro. Leva-se quase sempre em conta apenas o aspecto pecuniário da relação de trabalho, como se fosse o único decisivo. Vários exemplos haveria para mencionar, mas basta a alusão à monetarização do risco à saúde do trabalhador, com pagamento de adicionais pelo trabalho realizado em condições insalubres ou perigosas, já sublinhada pela doutrina. ${ }^{?}$

\footnotetext{
Livro IV, Título 93.

7 Cf., mais extensamente, OLIVEIRA, Sebastião Geraldo de. Proteção jurídica à saúde do trabalhador. São Paulo: LTr, 2002. p. 138 e ss.
} 
De outra parte - eis o segundo ponto a notar no art. $5^{\circ}$, da CLT -, é significativa a referência apenas à discriminação fundada em motivo de sexo, como se aí estivesse a única hipótese de discriminação. A explicação para a referência restrita do legislador - quando muito mais acertada seria previsão ampla, excludente de qualquer forma de discriminação - resulta do peso histórico da discriminação por motivo de sexo, mesmo em países com maior tendência à igualdade. É, aliás, o que também justifica e explica a regra expressa do inciso I, art. $5^{\circ}$, da vigente Constituição, que se poderia ter por desnecessária, ante os termos gerais do caput, do mesmo dispositivo. ${ }^{8}$ Há passagens, em matéria de discriminação por motivo de sexo, muito expressivas, a demonstrar claramente como esteve ela entranhada na cultura ocidental, mesmo recente. Vale a pena dedicar algumas linhas ao problema.

Eloqüente, em primeiro lugar, trecho do voto apresentado na Suprema Corte norte-americana, pelo juiz Bradley, que, ao julgar caso envolvendo lei do Estado de Illinois, proibitiva do exercício da advocacia por mulheres, afirmou textualmente, em 1873:

"the civil law, as well as nature herself, has always recognized a wide difference in the respective spheres and destinies of man and woman. Man is, or should be, woman's protector and defender. The natural and proper timidity and delicacy which belongs to the female sex evidently unfits it for many of the occupations of civil life. The constitution of the family organization, which is founded in the divine ordinance, as well as in the nature of things, indicates the domestic sphere as that which properly belongs to the domain and functions of womanhood. The harmony, not to say identity, of interest and views which belong, or should belong, to the family institution is repugnant to the idea of a woman adopting a distinct and independent career from that of her husband... The paramount destiny and mission of woman are to fulfill the noble and benign offices of wife and mother. This is the law of the Creator. And the rules of civil society must be adapted to the general constitution of things, and cannot be based upon exceptional cases". 9

Com tais fundamentos, a Suprema Corte considerou constitucional e não ofensiva às garantias conferidas aos cidadãos americanos a proibição estabelecida pelo

\footnotetext{
8 A propósito, cf. MIRANDA, Francisco Cavalcanti Pontes de. Comentários à Constituição de 1967. Rio de Janeiro: Forense, 1987. tomo IV, p. 708.

9 Bradwell v. State of Illinois, 83 US 130. As passagens transcritas encontram-se a p. 141 e 142. A decisão, hoje considerada aberrante, contou apenas com o voto vencido do Chief Justice Samuel Chase.
} 
legislador estadual, com apenas um voto contrário e embora já estivesse em pleno vigor a XIV Emenda à Constituição, com a garantia de "equal protection". ${ }^{10}$

Passadas sete décadas, em 1948, o assunto voltou à Suprema Corte. Discutiu-se a validade de lei que vedava o trabalho de mulheres em bares. Questionou-se a constitucionalidade dessa proibição. Agora com margem mais estreita, por 6 votos contra 3 , conclui o tribunal que a lei era constitucional, porque bar não era lugar para uma mulher exercer sua atividade. ${ }^{11}$

Já em 1961 - as datas são muito significativas para que se perceba como a discriminação por motivo de sexo esteve mesmo muito entranhada na cultura ocidental - outra vez se reconheceu a legitimidade do tratamento discriminatório em face da mulher. Tratava-se de lei do Estado da Flórida que excluía a participação das mulheres da composição dos júris, instituição que, como todos sabem, tem papel importantíssimo no processo penal e também no processo civil norte-americano. Pois bem, a Corte Suprema concluiu que o tratamento diferenciado entre homens e mulheres, no que toca ao serviço no júri, não era inconstitucional. Como assinalou a Corte, em decisão redigida pelo Juiz Harlan: "Woman is still regarded as the center of home and family life", o que permitiria legitimamente dispensa legal de servir em tribunal do júri, "unless she herself determines that such service is consistent with her own special responsabilities". ${ }^{12}$

São muito significativas as datas das decisões. Oito anos antes do julgamento envolvendo a lei do Estado da Flórida, ou seja, em 1953, a mesma Suprema Corte dos Estados Unidos havia destruído, ao menos em termos formais, os pilares jurídicos da discriminação racial, com o famoso julgamento proferido no caso Brown v. Board of Education, que eliminou a segregação racial nos colégios. ${ }^{13}$ Permaneceriam, contudo, por quase uma década, os pilares jurídicos da discriminação contra a mulher.

Em outros países, talvez mais próximos da cultura e realidade brasileiras, o quadro não se desenhou de forma diversa. Tenha-se em mente o que se deu na Itália, após a Constituição democrática e social de 1947, que é categórica ao proibir discriminação

\footnotetext{
${ }^{10}$ Consta da seç̧ão 1 da referida emenda, cuja vigência foi certificada em 1868: “All persons born or naturalized in the United States and subject to the jurisdiction thereof, are citizens of the United States and of the State wherein they reside. No State shall make or enforce any law which shall abridge the privileges or immunities of citizens of the United States; nor shall any State deprive any person of life, liberty, or property, without due process of law; nor deny to any person within its jurisdiction the equal protection of the laws".

${ }^{11}$ Goesaert v. Cleary, 335 U.S. 464. Ficaram vencidos os juízes Rutledge, Douglas e Murphy. Coube ao juiz Frankfurter redigir a decisão tomada pela maioria, na qual registrou: "Michigan could, beyond question, forbid all women from working behind a bar. This is so despite the vast changes in the social and legal position of women. The fact that women may now have achieved the virtues that men have long claimed as their prerogatives and now indulge in vices that men have long practiced, does not preclude the States from drawing a sharp line between the sexes, certainly, in such matters as the regulation of the liquor traffic" (p. 465-466).

${ }^{12}$ Hoyt v. Florida (368 U.S. 57).

13347 U.S. 483.
} 
entre homem e mulher, ao dispor, no art. 3: "Tutti i cittadini hanno pari dignità sociale e sono eguali davanti alla legge, senza distinzione di sesso, di razza, di lingua, di religione, di opinioni politiche, di condizioni personali e sociali". Em 1961, porém, a Corte Constitucional italiana teve de se defrontar com um caso muito marcante. $\mathrm{O}$ art. 559 do Código Penal italiano pune o adultério. Mas o faz tão-somente a propósito do adultério cometido pela mulher. $\mathrm{O}$ texto dizia o seguinte: "La moglie adultera è punita con la reclusione fino a un anno". Não há dúvida quanto ao significado da norma. A punição é dirigida, no tocante aos cônjuges, apenas à mulher, não ao homem. Discutiu-se, em conseqüência, a constitucionalidade da punição unicamente do adultério feminino. Em 1961, a Corte Constitucional, na sentença n. 64, chegou à conclusão de que a diferença de tratamento refletiria legítima valoração estabelecida pelo legislador, insuscetível de controle pela jurisdição constitucional. São surpreendentes os termos da decisão: "Il principio di eguaglianza di cui all'art. 3 della Costituzione, diretto ad impedire che a danno dei cittadini siano dalle leggi disposte discriminazioni arbitrarie, non può significare che il legislatore sia obbligato a disporre per tutti una identica disciplina, mentre, al contrario, deve essergli consentito di adeguare le norme giuridiche ai vari aspetti della vita sociale, dettando norme diverse per situazioni diverse. Pertanto con l'art. 559 c.p. che punisce soltanto l'adulterio della moglie e non pone condizioni alla punibilità della relazione adulterina della moglie, non è stata creata a carico di questa una posizione di inferiorità, ma soltanto è stata diversamente disciplinata una situazione che il legislatore ha ritenuta diversa. Spetta al legislatore, non alla Corte Costituzionale, lo stabilire se la norma in questione risponda alla attuale valutazione sociale dei rapporti fra i coniugi e se i meriti oppure no di essere modificata". Rejeitou-se, assim, a alegação de inconstitucionalidade e manteve-se o tratamento discriminatório.

Felizmente, porém, não existe, no sistema italiano, a descabida e indesejável regra incorporada ao ordenamento jurídico brasileiro, segundo a qual a decisão que afirma a constitucionalidade da lei é imutável. ${ }^{14}$ Por isso, a afirmação da constitucionalidade do art. 559, do Código Penal italiano, pôde ser novamente reexaminada sete anos

\footnotetext{
${ }^{14}$ Nos termos do art. 26, da Lei n. 9.868, “A decisão que declara a constitucionalidade ou a inconstitucionalidade da lei ou do ato normativo em ação direta ou em ação declaratória é irrecorrível, ressalvada a interposição de embargos declaratórios, não podendo, igualmente, ser objeto de ação rescisória". Para exame do problema, no sistema italiano, com expressa afirmação do caráter não definitivo da decisão que afirma a constitucionalidade de certa lei, cf. CRISAFULLI, Vezio. Lezioni di diritto constituzioanale. Padova: CEDAM, 1974. II, 2, p. 151. A mesma solução prevalece no Direito português, como mostra MIRANDA, Jorge. Manual de Direito Constitucional. Coimbra: Coimbra Editora, 1996. tomo II, p. 483. A razão para a revisibilidade da decisão declaratória de constitucionalidade é simples. A interpretação constitucional é necessariamente evolutiva. A Constituição não é um texto apenas jurídico, mas também um texto político. $\mathrm{O}$ significado dado à norma em certa altura poderá não ser o mesmo depois de passado algum tempo. Nas palavras de Girgio Berti: "l'interpretazione si denota per la continuità e l'adattabilità all'evoluzione della vita sociale e dei rapporti giuridici e non c'è mai una definività assoluta, una forza di giudicato dell'atto interpretativo che non consenta
} 
depois, em 1968. Agora, já em ambiente distinto, sob a presidência de um dos maiores administrativistas italianos, Aldo Sandulli, afirmou a Corte, com sua sentença n. 126, a inconstitucionalidade da norma penal questionada, porque discriminatória a distinção estabelecida. A sentença tem a seguinte ementa: "Per l'unità familiare costituisce indubbiamente un pericolo sia l'adulterio del marito sia quello della moglie; ma quando la legge faccia un differente trattamento, questo pericolo assume proporzioni più gravi, sia per i riflessi sul comportamento di entrambi i coniugi, sia per le conseguenze psicologiche sui soggetti. Pertanto, i commi primo e secondo dell'art. 559 del codice penale sono viziati di illegittimità costituzionale in riferimento agli artt. 3 e 29 della Costituzione, in quanto sanciscono una deroga al principio di eguaglianza dei coniugi non essenziale per la garanzia dell'unita'familiare, ma risolventesi, piuttosto, per il marito, in un privilegio; e questo, come tutti i privilegi, viola il principio di parità". O art. 559, do Código Penal italiano, deixou, em conseqüência, de viger.

No Brasil, após a Constituição, de 1988, ainda se encontrava na jurisprudência, inclusive do Tribunal Superior do Trabalho, a afirmação da necessidade de tratamento diferenciado da mulher, com proibição de elastecimento, por meio de negociação coletiva, de intervalo intrajornada, prevista no art. 383, da CLT, diversamente do quanto estabelecido para o homem, ${ }^{15}$ conclusão que dificilmente se harmoniza com a idéia mais ampla de igualdade entre homens e mulheres. ${ }^{16}$

Em síntese, a persistência, ao longo do tempo, da discriminação por motivo de sexo, discriminação por vezes referendada pelo próprio legislador, como no caso do

di rivederne i pressupposti, quando questi mutino"(BERTI, Girgio. Interpretazione costituzionale. Padova: CEDAM, 1990. p. 619).

15 "Horas extras provenientes da ampliação do intervalo de intrajornada - art. 383 da CLT. A correlação lógica entre o fator objetivo e a discriminação procedida impede que esta se constitua em violação do principio da igualdade. É a hipótese do art. 383 da CLT que se dirige à proteção do trabalho da mulher. A natureza não fez homens e mulheres iguais: a desigualdade é visível e não poderia ser modificada por simples vontade do legislador. Assim é que a igualdade consiste em tratar igualmente os iguais e desigualmente os desiguais, na medida de sua desigualdade. Sendo claro que a constituição física, emocional e psicológica das pessoas do sexo feminino difere daquela inerente às do sexo masculino, é um imperativo de justiça que o tratamento dado em relação às mulheres, pela legislação trabalhista, seja, em alguns aspectos, diferente do que é dado aos homens. Com base nisso, a regra de proteção ao trabalho da mulher insculpida no art. 383 da CLT é lógica e razoável, já que presente a correlação lógica entre o fator objetivo e a diferenciação de tratamento elencada. Trata-se de norma cogente do Direito do Trabalho, recepcionada pela Constituição Federal de mil novecentos e oitenta e oito, não podendo ser modificada por acordo entre as partes. Devidas, pois, as horas extras pleiteadas. Revista conhecida por violação do art. 383 da CLT e provida no mérito, para restabelecer a r. sentença de primeiro grau.” (TST - 5 T., Ac. n. 2656, Proc. RR n. 48.478, Rel. Min. Armando de Brito, julg. em 23.06.94 in DJU de 19.08.94, p. 21.009).

16 Por isso afirma a doutrina a incompatibilidade do art. 384, da CLT - que exige intervalo de 15 minutos antes da prestação de horas extras por mulheres, previsão sem correspondente para os homens - com a igualdade constitucional entre homens e mulheres. Cf., entre outros autores, BARROS, Alice Monteiro de. Curso de Direito do Trabalho. São Paulo: LTr, 2005. p. 1.029), SAAD, Eduardo Gabriel. CLT comentada. São Paulo: LTr, 2001. p. 241) e OLIVEIRA, Francisco Antonio de. CLT comentada. São Paulo: RT, 2000. p. 257). 
art. 383, da CLT, é que explica a regra do art. $5^{\circ}$, da CLT. É também o que explica o fato de a norma geral contra a discriminação, inserida no texto da CLT em data recente, figurar exatamente no Capítulo que cuida do trabalho da mulher. Trata-se do art. 373A, introduzido pela Lei n. 9.799, que, embora integrado a seguimento específico do diploma legal, enuncia regra geral contrária à discriminação, abrangendo não apenas a discriminação por motivo de sexo como, igualmente, por outros motivos. ${ }^{17}$

\section{Discriminação por motivo de raça}

Menção particularizada deve ser feita à discriminação racial.

Há uma idéia generalizada de que no Brasil a discriminação racial é muito menos intensa e muito menos acentuada do que a encontrada em outros países. Isso se deveria, segundo a conhecida concepção de Gilberto Freyre, à colonização portuguesa, tida como menos segregacionista no tratamento dispensado aos escravos, permitindo mais facilmente a miscigenação. Afirmou ele que a escravidão portuguesa não seria a escravidão violenta que existiu, por exemplo, nos Estados Unidos, mas uma escravidão adaptada aos trópicos, fazendo com que a discriminação racial fosse muito menos intensa, ${ }^{18}$ a gerar, inclusive, o mito da assim chamada democracia racial. Esse julgamento não retrata bem a realidade.

Não se deve perder de vista, em primeiro lugar, que o Brasil foi um dos últimos países do mundo em que eliminada a escravidão, após quase 400 anos da prática. E os efeitos de tão largo período de tempo não se apagam, de nenhuma forma, do dia para noite. Em segundo lugar, os sinais de discriminação contra negros na sociedade são inegáveis. Dispensam até mesmo exemplificação detalhada. ${ }^{19}$ Não existe aqui, com certeza, a discriminação explícita, encontrada nos Estados Unidos da América, país em que, até 1953, com a decisão tomada no caso Brown v. Board of Education, já mencionada, ainda prevalecia a tese da legitimidade do tratamento diferenciado entre brancos e negros, firmada no final do século XIX, quando do julgamento Plessy v. Ferguson, ${ }^{20}$ seguramente

\footnotetext{
${ }^{17}$ Sobre o tema da discriminação por motivo de sexo, com o seu exame por diferentes autores, tendo em conta vários sistemas jurídicos, cf., obra coletiva (PENIDO, Laís de Oliveira (Coord.). A igualdade dos gêneros nas relações de trabalho. Brasília: Escola Superior do Ministério Público da União, 2006. passim.

${ }^{18}$ FREYRE, Gilberto. Casa-Grande \& Senzala. Brasília: Editora da Universidade de Brasília, 1963. passim.

${ }^{19}$ Cf., mais amplamente sobre o tema, TELLES, Edward. Racismo à brasileira: uma nova perspectiva sociológica. Rio de Janeiro: Relume, 2003, passim, bem como ROLAND, Edna Maria Santos. The economics of racism: people of african descent in Brazil. In: SEMINAR ON THE ECONOMICS OF RACISM. The International Council on Human Rights Policy, Geneva, 2001. passim.

${ }^{20} 163$ U.S. 537. Na decisão, que soa hoje como bárbara e inacreditável, afirma-se: "A statute which implies merely a legal distinction between the white and colored races - a distinction which is founded in the color of the two races, and which must always exist so long as white men are distinguished from the other race by
} 
um dos mais infelizes pronunciamentos da Suprema Corte norte-americana ${ }^{21}$, a partir do qual se formou a doutrina do equal but separete. No Brasil, porém, a discriminação, se não é ostensiva, costuma apresentar-se de forma mais dissimulada, oculta, disfarçada. Com isso o problema não desaparece. Pelo contrário. Torna-se ainda mais grave, dado que mais difícil de identificar e de combater. Daí a reação firme do legislador, não-só com o repúdio formal ao racismo ${ }^{22}$ como, igualmente, com a tipificação de sua prática como crime "inafiançável e imprescritível", punível com pena de reclusão. ${ }^{23}$

\section{Outras formas de discriminação}

Além da discriminação por motivo de sexo ou de raça, existem muitas outras formas de discriminação, várias delas previstas em diferentes dispositivos da Constituição, da CLT ou de leis esparsas.

No art. $7^{\circ}$, inciso XXX, da Constituição, encontra-se, por exemplo, a referência à discriminação por motivo de idade e por motivo de estado civil, no tocante a salário, exercício de função e critério de admissão.

A discriminação por motivo de idade adquiriu alguma evidência com julgamento do Tribunal Superior do Trabalho, proferido no âmbito da $5^{\mathrm{a}}$ Turma, de que foi relator o Juiz Convocado André Luis Moraes de Oliveira. O caso envolvia empresa que dispensava sistematicamente trabalhadores com mais de 60 anos. O Tribunal Superior do Trabalho, antes mesmo de que estivesse em vigor a Lei n. 10.741, que expressamente proibiu a fixação de limite máximo de idade para o exercício de trabalho, ressalvados os casos em que a natureza da atividade justifique a exigência, ${ }^{24}$ reconheceu que o caso era de discriminação e acolheu o pedido de reintegração do trabalhador no emprego. ${ }^{25}$

color - has no tendency to destroy the legal equality of the two races, or re-establish a state of involuntary servitude" (p. 543).

21 Jeffrey Rosen diz tratar-se de decisão tão criticada como a tomada no caso Dred Scott, que declarou a obrigação do Congresso norte-americano de proteger os direitos dos senhores de escravo (cf. ROSEN, Jeffrey. The Supreme Court: the personalities and rivalries that defined America. New York: Times Books, 2006. p. 100).

${ }^{22}$ Constituição, art. $4^{\circ}$, inciso VIII.

${ }^{23}$ Constituição, art. $5^{\circ}$, XLII.

${ }^{24}$ Trata-se da regra editada pelo art. 27, do Estatuto do Idoso, de seguinte teor: "Na admissão do idoso em qualquer trabalho ou emprego, é vedada a discriminação e a fixação de limite máximo de idade, inclusive para concursos, ressalvados os casos em que a natureza do cargo o exigir".

${ }^{25} \mathrm{O}$ acórdão tem a seguinte ementa: "Recurso de revista. Dispensa discriminatória por idade. Nulidade. Abuso de direito. Reintegração. Se das premissas fáticas emergiu que a empresa se utiliza da prática de dispensar seus funcionários quando estes completam 60 anos, imperioso se impõe ao julgador coibir tais procedimentos irregulares, efetivados sob o manto do "poder potestativo", para que as dispensas não se efetivem sob a pecha discriminatória da maior idade. Embora o caso vertente não tivesse à época de sua ocorrência previsão legal especial (a Lei n. 9.029 que trata da proibição de práticas discriminatórias foi editada em 13.04.1995 e a dispensa do reclamante ocorreu anteriormente), cabe ao prolator da decisão o dever de valer-se dos princípios gerais do direito, da analogia e dos costumes, para solucionar os conflitos a ele impostos, sendo esse, aliás, 
Sem embargo das hipóteses mencionadas, o certo é que esse art. $7^{\circ}$, inciso XXX, da Constituição, traça apenas parâmetros exemplificativos. A Constituição - podese claramente inferir isso do seu sistema e, especialmente, da parte final do seu art. $3^{\circ}$, inciso IV - proíbe genericamente qualquer forma de discriminação. Aliás, outras formas de discriminação acham-se mencionadas em dispositivos diversos, mas que têm toda a pertinência no campo do Direito do Trabalho. Considere-se, por exemplo, que o art. $7^{\circ}$, inciso XXX, não se refere à discriminação por motivo de crença religiosa. Mas o art. $5^{\circ}$, inciso VIII, da mesma Constituição, alude à proibição de discriminação por esse motivo, solução que se estende, sem dúvida nenhuma, ao campo do Direito do Trabalho.

O mesmo se pode dizer a propósito da situação familiar, que é mencionada no art. 373, da CLT, e na Lei n. 9.029. A filiação, como causa de discriminação, é completamente repudiada. Não se pode, por conta da filiação do trabalhador, negar-lhe certo direito. A recíproca é igualmente verdadeira. Tampouco se pode favorecer alguém em virtude de sua filiação. A conclusão a que chegou a Suprema Corte norte-americana em Kotch v. Board of River Port Pilot Com'rs for Port of New Orleans, ao validar a seleção de novos pilotos de navio feita de modo a favorecer sempre "relatives and friends", ${ }^{26}$ não é correta. É muito pouco provável que hoje fosse reiterada. ${ }^{27}$

Tampouco a discriminação por convicção filosófica ou política é aceitável. Como notou a United States Court of Appeals for the First Circuit, em proposição passível de generalização, “... as a general rule, a government employer cannot discharge public employees merely because they are not sponsored by or affiliated with a particular political

o entendimento consagrado pelo art. $8^{\circ}$, da CLT, que admite que a aplicação da norma jurídica em cada caso concreto, não desenvolve apenas o dispositivo imediatamente específico para o caso, ou o vazio de que se ressente, mas sim, todo o universo de normas vigentes, os precedentes, a evolução da sociedade, os princípios, ainda que não haja omissão na norma. Se a realidade do ordenamento jurídico trabalhista contempla o direito potestativo da resilição unilateral do contrato de trabalho, é verdade que o exercício deste direito guarda parâmetros éticos e sociais como forma de preservar a dignidade do cidadão trabalhador. A despedida levada a efeito pela reclamada, embora cunhada no seu direito potestativo de resilição contratual, estava prenhe de mácula pelo seu conteúdo discriminatório, sendo nula de pleno direito, em face da expressa disposição do art. $9^{\circ}$ da CLT, não gerando qualquer efeito, tendo como conseqüência jurídica a continuidade da relação de emprego, que se efetiva através da reintegração. Efetivamente, é a aplicação da regra do $\S 1^{\circ}$ do art. $5^{\circ}$ da Constituição Federal, que impõe a aplicação imediata das normas definidoras dos direitos e garantias fundamentais, pois, como apontando pelo v. acórdão, a prática da dispensa discriminatória por idade confrontou o princípio da igualdade contemplado no "caput" do art. $5^{\circ}$ da Constituição Federal. Inocorrência de vulneração ao princípio da legalidade e não configurada divergência jurisprudencial. Recurso de Revista não conhecido relativamente ao tema". (TST $-5^{\mathrm{a}}$ T., RR n. 462.888, Rel. Juiz Convocado André Luís Moraes de Oliveira, julg. em 10.09.03 in DJU de 26.09.03). Sobre o tema, amplamente, cf. Emmanuel Teófilo Furtado, Preconceito no trabalho e a discriminação por idade, São Paulo, LTr, 2004, passim.

26330 U.S. 552.

${ }^{27}$ Tinha toda razão o juiz Rutledge ao anotar, na sua dissenting opinion: "the result of the decision therefore is to approve as constitutional state regulation which makes admission to the ranks of pilots turn finally on consanguinity. Blood is, in effect, made the crux of selection. That, in my opinion, is forbidden by the fourteenth amendment's guaranty against denial of the equal protection of the laws" (330 U.S. 565). 
party...". ${ }^{28}$ Admitir a rescisão de contrato de trabalho, por o empregado, condutor de trens de metrô ou professor em escola pública, recusar-se a responder se é ou-não filiado a determinado partido político, como fez a Suprema Corte dos Estados Unidos em Lerner v. Casey ${ }^{29}$ e, de novo, em Beilan v.Board of Education, ${ }^{30}$ não é de nenhuma forma aceitável. A pergunta nem pode ter lugar. ${ }^{31}$ Como realçado no Código do Trabalho de Portugal, o direito à reserva sobre a intimidade no âmbito da relação de emprego compreende a preservação de informações relacionadas com "a vida familiar, afectiva e sexual, com o estado de saúde e com as convicções políticas e religiosas". ${ }^{32}$

É igualmente proscrita a discriminação decorrente da procedência da pessoa, como referido, a propósito da procedência nacional, pelo art. 20, da Lei n. 7.716. ${ }^{33}$ Impor tratamento diferenciado a trabalhadores, por conta de sua origem geográfica, é ilícito, conquanto se cuide de prática não de todo rara no País.

Há ainda mais formas de discriminação a referir, como, entre outras, as indicadas pela Lei belga de 10 de maio de 2007, a saber, opção sexual, fortuna, características genéticas, língua e origem social. ${ }^{34}$ Nenhuma delas se admite, ainda que não exista previsão expressa no Direito brasileiro. Importa o princípio geral de proibição de discriminação, enunciado em julgado do Tribunal Superior do Trabalho, em caso em que se examinou prática discriminatória contra empregado infectado pelo vírus HIV. "Empregada portadora do vírus HIV. Dispensa discriminatória. A SDI-I do TST firmou posicionamento no sentido de que, ainda que não exista, no âmbito infraconstitucional, lei específica asseguradora da permanência no emprego do empregado portador do vírus HIV, a dispensa de forma arbitrária e discriminatória afronta o "caput" do art. $5^{\circ}$ da CF/88. Precedentes: ERR 439.041/1998, ERR 217.791/1995, ERR 205.359/1995. Recurso de revista conhecido e parcialmente provido". ${ }^{35}$

Mencione-se, ainda, a discriminação genética, propiciada pelo avanço científico, a permitir, a partir de exame do DNA, antecipar a tendência de certas pessoas para o desenvolvimento de algumas doenças, o que possibilitaria - como já se noticia ${ }^{36}$

\footnotetext{
${ }_{28}$ Benito Galloza et al., v. Norman E. Foy et al., n. 03-2658.

29357 U.S. 468.

30357 U.S. 399.

31 PALOMEQUE LÓPEZ, Manuel Carlos; ALVAREZ DE LA ROSA, Manuel. Derecho del trabajo: Madrid: Editorial Centro de Estúdios, 2001.p. 707.

32 Art. $16^{\circ}$, n. 2 .

${ }^{33} \mathrm{O}$ dispositivo tipifica como crime o seguinte: "Praticar, induzir ou incitar a discriminação ou preconceito de raça, cor, etnia, religião ou procedência nacional".

${ }^{34}$ Art. $4^{\circ}$, n. $4^{\circ}$.

35 TST - 5 $5^{\text {a }}$., RR n. 726.101/2001, Rel. Min. Rider Nogueira de Brito, julg. em 26.11.2003 in DJU de 06.02.2004.

${ }^{36}$ Cf. O artigo "Clandestinidade genética", publicado no jornal Folha de S. Paulo, 2 de março de 2008, caderno mais!, p. 9
} 
- preteri-las não-somente no campo do trabalho como, outrossim, em outros setores, inclusive em matéria de acesso a serviços de saúde, especialmente aqueles propiciados por planos de assistência médica. Daí a importância da regra do art. $22^{\circ}$, n. 2 , do Código do Trabalho de Portugal, que oportunamente se ocupou do problema e dispôs, entre outras coisas: "Nenhum trabalhador ou candidato a emprego pode ser privilegiado, beneficiado, prejudicado, privado de qualquer direito ou isento de qualquer dever em razão, nomeadamente, de...património genético...".

Por fim, sem a pretensão de oferecer rol exaustivo, vale mencionar a discriminação provocada pelo exercício do direito de ação. Deixar de admitir o trabalhador, em virtude de ter ele ajuizado reclamação em face de seu antigo empregador, é prática ilícita, já sancionada pelos tribunais, com deferimento de indenização, como mostra decisão assim ementada: “...o direito de ação é constitucionalmente assegurado (art. $5^{\circ}$, XXXV) e as chamadas "listas negras" são de há muito repudiadas pelo ordenamento jurídico, por impedir, injustamente, a admissão de trabalhadores que exerceram direito legitimamente assegurado. Assim, demonstrado que a atitude da Reclamada foi lesiva à honra e à intimidade do Reclamante, causando-lhe frustração pela oportunidade perdida injustamente, indubitável o dano moral ocasionado e a relação de causalidade entre o ato e o efeito, pelo que deve ser deferida a indenização específica, ressaltando ainda o caráter pedagógico da pena, que visa a coibir a prática discriminatória, pela Reclamada". ${ }^{37}$

\section{Discriminação e diferença de tratamento}

Na presente altura, depois do que já se disse sobre as diferentes formas de discriminação, há uma observação a fazer. A proibição de discriminação - que, como se procurou mostrar, é muito ampla, a compreender, inclusive, situações não-previstas expressamente pelo legislador - não significa imposição de igualdade absoluta entre as pessoas.

Seria, no fundo, erro evidente compreender o princípio da igualdade ou a proibição de discriminação como imposição de igualdade absoluta, linear e completa entre todos. Como notou Duguit, querer tirar da garantia de isonomia exigência de identidade matemática seria o paradoxo da igualdade, que levaria muito mais à desigualdade. ${ }^{38} \mathrm{E}$ decidiu bem o Tribunal Superior do Trabalho ao admitir a diferenciação de empregados

\footnotetext{
${ }^{37}$ TRT - $3^{\text {a }}$ Reg., RO n. 00951-2005-015-03-004, Rel. Juiz Fernando Luiz Gonçalves Rios Neto, julg. em 05.07.2006 in DJMG de 15.07.2006, p. 13.

${ }^{38}$ DUGUIT, Leon. Traité de droit constitutionnel. Paris: Ancienne Librairie Fontemoing \& Cie., 1923. tome troisième, p. 585.
} 
que exerciam atividades diversas, com concessão a uns de vantagens não estendidas a outros. ${ }^{39}$

O que se proíbe, o que todos os dispositivos legais antes citados vedam, o que a evolução da sociedade proscreve, é a discriminação desarrazoada ou descabida. Em outros termos, o que o princípio da igualdade tolhe são "differenziazioni arbitrarie". ${ }^{40}$ Não impede que se estabeleçam distinções, até porque o papel da lei é, em grande medida, fazer distinções. Proíbe-se, com a regra da igualdade, como assentou o Tribunal Constitucional de Portugal, apenas que se estabeleçam distinções “arbitrárias ou irrazoáveis, porque carecidas de fundamento material bastante. Dizer igualdade - prossegue a decisão - é afirmar a proibição do arbítrio, do irrazoável, do injustificado". ${ }^{41}$ Para repetir a observação de Guilherme Machado Dray, "sendo admissíveis as diferenciações, o que se pede e exige é que estas sejam materialmente fundadas e se baseiem numa distinção objectiva de situações". ${ }^{42}$ Em resumo, diante da conotação que a palavra já adquiriu, pode-se afirmar que proibida é, tão-somente, a discriminação e não a mera diferenciação, que é algo diverso e que se pode admitir.

É interessante, no particular, voltar a atenção para o Código do Trabalho de Portugal, já antes mencionado. O legislador português tratou com bastante acerto do assunto, porque foi muito mais abrangente do que a limitada regra do art. $373 \mathrm{~A}$, da CLT. Preceitua o art. 23, n. 1, do Código do Trabalho de Portugal, que trata da proibição da discriminação: "o empregador não pode praticar qualquer discriminação: direta ou indireta baseada nomeadamente na ascendência, idade, sexo, orientação sexual, estado civil, situação familiar, patrimônio genético, capacidade de trabalho reduzida, deficiência ou doença crônica, nacionalidade, origem étnica, religião, convicções políticas ou ideológicas e filiação sindical". Embora o rol seja bastante amplo, não perde o seu caráter exemplificativo, realçado pela doutrina. ${ }^{43} \mathrm{O}$ legislador apenas procurou, com a menção a grande número de situações, dar máxima abrangência ao enunciado, tudo para mostrar que

\footnotetext{
${ }_{39}$ Cuida-se de julgado assim ementado: “Adicional de nível universitário. Se instituído o adicional de nível universitário apenas para os advogados, não há amparo legal para a extensão da vantagem aos economistas, sob o fundamento de que deve ser aplicado o princípio isonômico, mesmo porque este não pode se sobrepor ao poder diretivo e de administração do empregador, respeitados os princípios básicos de proteção ao trabalho. Revista parcialmente conhecida e provida". (TST - $1^{\mathrm{a}}$ T., RR n. 298.012, Rel. Juiz Convocado Domingos Spina, julg. em 17.11.99 in DJU de 11.02.00, p. 50)

${ }^{40}$ PALLIERI, Balladore. Diritto costituzionale. Milano: Giuffrè, 1963. n. 122, p. 366. Na mesma linha, com indicação de precedente da Corte Constitucional alemã, cf. CURRIE, David P. The Constitution of the Federal Republic of Germany. Chicago: The University of Chicago Press, 1994. p. 322.

41 Processo n. 249/91, Rel. Messias Bento, acórdão n. 226/92, decisão de 17.06.1992. A passagem transcrita acha-se no n. 7, da decisão.

42 DRAY, Guilherme Machado. O princípio da igualdade no Direito do Trabalho. Coimbra: Almedina, 1999. n. 125 , p. 109.

${ }^{43}$ GOMES, Júlio Manuel Vieira. Direito do trabalho. Coimbra: Coimbra Editora, 2007. v. 1, p. 423, e QUINTAS, Paula; QUINTAS, Helder. Código do trabalho: anotado e comentado. Coimbra: Almedina, 2004. p. 136.
} 
qualquer forma de diferenciação desarrazoada ou discriminação está afastada do ponto de vista legal.

Mas - daí a importância da referência ao dispositivo do Código do Trabalho de Portugal - proibição de discriminação não é sinônimo de proibição de diferenciação. Certas diferenças precisam ser estabelecidas. E o legislador português tinha isso em mente quando, logo na alínea n. 2, do mesmo art. 23, dispôs: "não constitui discriminação o comportamento baseado num dos fatores indicados no número anterior sempre que, em virtude da natureza das atividades profissionais em causa ou do contexto de sua execução, esse fator constitua um requisito justificável e determinante para o exercício da atividade profissional, devendo o objetivo ser legítimo e o requisito proporcional". Retoma-se a idéia que havia sido esboçada acima. O que se proscreve é simplesmente a discriminação, ou seja, a diferenciação abusiva, que não tem causa justa. ${ }^{44}$ Não toda e qualquer diferenciação.

É claro que o problema, assim colocado, não se resolve por inteiro. A dificuldade que remanesce está exatamente em determinar aquilo que é justificável ounão no campo da diferenciação. Para a Suprema Corte norte-americana o sexo era, no exercício da advocacia, em 1873, um elemento de diferenciação justificável, como se infere do exemplo já dado no presente texto. O passar do tempo deixou patente o erro da conclusão, que ninguém mais hoje subscreveria.

No Direito, porém, as linhas nem sempre são nítidas, nem sempre cortam com precisão. O que atualmente se vê, com toda clareza e transparência, como um erro grave, inaceitável mesmo, ontem parecia normal e inevitável. ${ }^{45} \mathrm{E}$ o que hoje se admite talvez amanhã venha a revelar-se intolerável. Há zonas cinzentas, em que as soluções se mostram mais difíceis. ${ }^{46}$ Basta pensar no caso, que não é hipotético, da discriminação, no trabalho, por motivo de crença religiosa. Se levantada a dúvida sobre a legitimidade de se condicionar o acesso ao emprego ou a permanência nele ao fato de o trabalhador professar determinada religião, o impulso inicial é claramente no sentido de repelir-se o critério, por inaceitável. Mas, caminhando na direção da zona cinzenta lembrada, a assertiva torna-se mais complexa. Caso o empregador seja, por exemplo, uma escola confessional, com todo o seu ensino a determinada religião, mantém-se o caráter inaceitável do critério? Continuará

\footnotetext{
${ }^{44}$ A propósito, RAPOSO, Vera Lúcia. Os limites da igualdade: um enigma por desvendar In: PENIDO, Laís de Oliveira (Coord.). A igualdade dos gêneros nas relações de trabalho. Brasília: Escola Superior do Ministério Público da União, 2006. p. 169-171.

${ }^{45} \mathrm{O}$ defloramento da mulher, ignorado pelo marido, como erro suficiente à anulação de casamento, nos termos do art. 219, inciso IV, do Código Civil de 1916, é exemplo bastante expressivo de algo considerado normal no passado e hoje visto como clara aberração. Torna-se ainda mais eloqüente o exemplo quando considerada a assertiva de João Luiz Alves, para quem a regra do inciso IV seria, em rigor, desnecessária, pois o defloramento estaria compreendido implicitamente na previsão do inciso III, ante a referência, neste último, a "defeito físico irremediável”! (Código Civil. São Paulo: Saraiva, 1935. v. 1, p. 249).

${ }^{46}$ Em termos semelhantes, cf. MELLO, Celso Antônio Bandeira de. Conteúdo jurídico do princípio da igualdade. São Paulo: Malheiros, 2006. n. 34, p. 39.
} 
a ser arbitrária a não-admissão de todos aqueles trabalhadores que não professam essa mesma religião? A jurisprudência italiana deu à questão resposta negativa. Concluiu que o critério é legítimo. Considerou a religião, em escola confessional, aspecto validamente determinante para a admissão do trabalhador, conforme sentença n. 195, proferida em 1972, na qual se afirma:

La libertà della scuola intesa come attuazione del principio del pluralismo scolastico ai sensi dell'art. 33 Cost., si estende indubbiamente alle università, per cui è ammissibile la creazione di università libere, che possono essere confessionali o comunque ideologicamente caratterizzate, e ne deriva necessariamente che la libertà di insegnamento da parte di singoli docenti che sono liberi di aderire all'indirizzo della scuola come di recedere dal relativo rapporto, incontra nel particolare ordinamento di siffatte università i limiti necessari a realizzarne le finalità. Ciò vale in particolare per l'Università cattolica la cui pretesa natura di persona giuridica pubblica non ne attenuerebbe comunque l'originaria destinazione finalistica e la caratterizzazione confessionale. Negando ad una libera università ideologicamente qualificata il potere di scegliere i suoi docenti in base ad una valutazione della loro personalità e negandosi alla stessa il potere di recedere dal rapporto ove gli indirizzi religiosi o ideologici del docente siano divenuti contrastanti con quelli che caratterizzano la scuola, si mortificherebbe e rinnegherebbe la libertà di questa, inconcepibile senza la titolarità di quei poteri, e pertanto l'art. 38 del Concordato non contrasta con l'art. 33 Cost., che subordina al nulla osta della S. Sede la nomina dei professori dell'Università cattolica del Sacro Cuore. La legittima esistenza di libere università caratterizzate dalla finalità di diffondere un credo religioso è uno strumento di libertà, e la libertà religiosa dei cattolici sarebbe gravemente compromessa ove l'Università cattolica non potesse recedere dal rapporto con un docente che più non ne condivida le fondamentali e caratterizzanti finalità. È pertanto infondata la questione di legittimità costituzionale dell'art. 38 del Concordato che subordina la nomina e la permanenza dei professori dell'Università cattolica al nulla osta della S. Sede, sollevata in relazione all'art. 19 Cost.

Em outros países, a diferença de tratamento, na situação mencionada, conta com a expressa permissão legislativa. É o que se dá, por exemplo, na Alemanha, em que a Lei geral sobre igualdade de tratamento (Allgemeines Gleichbehandlungsgesetz $-A G G$ ) admite distinção fundada em crença religiosa ou secularismo, no caso de emprego 
oferecido por comunidades religiosas, instituições associadas a elas ou, ainda, associações que tenham por finalidade cultivar determinada crença religiosa ou o secularismo. ${ }^{47}$

Nem mesmo nessa situação extrema, contudo, a distinção pode ser aceita. O decisivo é o conhecimento que se tem para o exercício do trabalho, não importando necessariamente a adesão a uma ou a outra religião ou a rejeição de todas elas. A decisão da Corte Constitucional italiana, antes referida e transcrita em parte, não levou em conta que a liberdade individual do empregador não se pode sobrepor ao interesse público de que não haja discriminação por motivo religioso. ${ }^{48}$

Outro exemplo das tantas dificuldades colocadas pelo exame da razoabilidade da distinção posta manifesta-se no plano político. É certo - como já exposto, aliás - não se admitir diferenciação de tratamento por motivo de convicção política. Mas - considerese agora o problema - como julgar a escolha feita para ocupar cargo de confiança na administração pública, a partir de critérios políticos, com exclusão de pessoas vinculadas a outros partidos? Haveria, no caso, discriminação, ou, ao contrário, simples diferenciação, aceitável ante o contexto em que realizada? A Suprema Corte americana, em Branti v. Finkel, disse que não havia discriminação, diante do caráter eminentemente político do cargo, que, na hipótese examinada, era de assessor de defensor público. Assinalou:

party affiliation is an appropriate requirement for the effective performance of the public office involved". ${ }^{49}$ Teve de admitir, porém: "it is not always easy to determine whether a position is one in which political affiliation is a legitimate factor to be considered. ${ }^{50}$

\section{Igualdade e ações afirmativas}

A discriminação, como visto até aqui, está claramente proibida e não é tolerada pelo ordenamento jurídico brasileiro. A realidade, no entanto, nem sempre condiz com tal idéia. A distância entre o dever ser - a norma legal - e o ser - aquilo que se passa no mundo dos fatos - é enorme. Por isso mesmo é que fica evidente como não basta proscrever, por meio da lei, a discriminação. É preciso eliminá-la da realidade. Eis o grande problema dos dias de hoje. A ilegalidade da discriminação já não está mais em causa. Não é aceita pelo ordenamento jurídico. Não é tolerada. O problema é que ela continua a ocorrer na

\footnotetext{
${ }^{47}$ Cf. $\S 9$, (1), do Allgemeines Gleichbehandlungsgesetz, na tradução para o inglês encontrada em Employment \& Labor Law in Germany, C. H. Beck e Ant. N. Sakkoulas, München, 2008, p. 128.

48 Sobre o tema, com conclusão divergente, porém, cf. MOREIRA, Teresa Alexandra Coelho. Da esfera privada do trabalho e o controlo do empregador. Coimbra: Coimbra Editora, 2004. p. 507 e ss. Note-se que, a despeito da data de publicação, o texto é anterior ao Código do Trabalho de Portugal.

49445 U.S. 507.

50 Idem.
} 
prática. Como eliminá-la? Como fazer com que a igualdade de tratamento, enunciada pela lei, transforme-se cada vez mais em realidade? Eis a questão hoje mais importante. Nesse campo há pelo menos dois aspectos fundamentais.

O primeiro envolve as chamadas ações afirmativas, caracterizadas, em linhas muito gerais, pelo tratamento desigual imposto pela lei, para compensar a desigualdade existente na realidade. $\mathrm{O}$ tema da ação afirmativa está atualmente em bastante evidência por conta de alteração legislativa ocorrida em alguns Estados da Federação, consistente na criação de cotas para ingresso, em universidades públicas, de estudantes vinculados a grupos minoritários ou desfavorecidos. Houve enorme polêmica sobre a legitimidade da previsão, com discussão em torno da própria constitucionalidade dessa reserva de cotas.

O que se alega, em oposição à ação afirmativa, é que a política no fundo viola a regra de tratamento igual de todos perante a lei. Afinal, se não pode haver discriminação, como privilegiar certa minoria ou certo grupo - nem sempre minoritário - com cotas reservadas, fazendo, por exemplo, com que aqueles que obtenham uma nota inferior possam ser admitidos na universidade em detrimento de outros, que não pertencem ao grupo e obtiveram notas superiores?

Ao enfrentar a questão lançada, prontamente vem à tona o julgamento da Suprema Corte americana que envolveu, mais uma vez, o problema da discriminação racial. A Universidade da Califórnia estabeleceu cotas reservadas para negros, hispânicos e outros grupos desfavorecidos na sociedade norte-americana. Questionou-se a legitimidade da providência e a Suprema Corte, em 1978, afirmou que as cotas eram inconstitucionais. ${ }^{51}$ Invoca-se esse precedente para justificar a mesma solução no Direito brasileiro. A forma como se conduz o debate é, todavia, incorreta, até porque a mesma Suprema Corte, em junho de 2003, reviu, em parte, sua posição. ${ }^{52}$ Afirmou, agora em relação ao sistema de cotas instituído pela Universidade de Michigan, que ele era legítimo, desde que o critério racial não fosse o único e convivesse com outros critérios. O resultado, de todo modo, é que, com o critério adotado, ingressarão na universidade integrantes de grupos desfavorecidos, mesmo que tenham obtido nota inferior à exigida de outros alunos. Como se vê, a Suprema Corte validou, em grande medida, a ação afirmativa. E mesmo antes, em 1970, no julgamento do caso Steelworkers v. Weber, reformou decisão da United States Court of Appeals for the Fifth Circuit, ao reconhecer a validade de norma coletiva celebrada com sindicato, em que prevista a promoção preferencial de trabalhadores negros, anteriormente preteridos no setor. ${ }^{53}$

\footnotetext{
${ }_{51}$ Regents of Univ. of Cal. v. Bakke (432 U. S. 265).

${ }^{52}$ Grutter v. Bollinger (000 U.S. 02-241).

53443 U.S. 193. Igualmente admitindo ações afirmativas, agora no campo da contratação de prestadores de serviços, veja-se a decisão tomada em Adarand Constructors, Inc. v. Pena, Certiorari to the United States Court of Appeals for the Tenth Circuit n. 93-1841, de 1995.
} 
Aliás, o resultado a que se chegou no Direito norte-americano está em linha com um dos dispositivos mais elegantes da Constituição italiana de 1947. O art. terceiro, que estabelece a regra geral de igualdade, dispõe, como já visto: "Tutti $i$ cittadini hanno pari dignità sociale e sono eguali davanti alla legge, senza distinzione di sesso, di razza, di lingua, di religione, di opinioni politiche, di condizioni personali e sociali". Esse é o enunciado geral que, tal como na Constituição italiana, aparece em muitas outras constituições. Mas o preceito verdadeiramente importante é o parágrafo único, que estabelece: " $E$ compito della Repubblica rimuovere gli ostacoli di ordine economico e sociale, che, limitando di fatto la libertà e l'eguaglianza dei cittadini, impediscono il pieno sviluppo della persona umana e l'effettiva partecipazione di tutti i lavoratori all'organizzazione politica, economica e sociale del Paese". Em termos semelhantes, a Constituição da Índia, estatui, no art. 15, sob a rubrica "prohibition of discrimination on grounds of religion, race, caste, sex or place of birth": “(1) The State shall not discriminate against any citizen on grounds only of religion, race, caste, sex, place of birth or any of them. (2) No citizen shall, on grounds only of religion, race, caste, sex, place of birth or any of them, be subject to any disability, liability, restriction or condition with regard to (a) access to shops, public restaurants, hotels and places of public entertainment; or (b) the use of wells, tanks, bathing ghats, roads and places of public resort maintained wholly or partly out of State funds or dedicated to the use of the general public". Sem embargo, logo no n. 3, do mesmo artigo, preceitua-se: "Nothing in this article or in clause (2) of article 29 shall prevent the State from making any special provision for the advancement of any socially and educationally backward classes of citizens or for the Scheduled Castes and the Scheduled Tribes".

A vigente Constituição brasileira, a despeito da consagração da igualdade formal, como se vê do caput, do art. $5^{\circ}$, segue a linha da Constituição italiana e da Constituição da Índia, ainda que não de maneira tão clara ou em termos tão expressos. Em seu art. $3^{\circ}$, inciso III, porém, inclui, entre os objetivos fundamentais da República, "erradicar a pobreza e a marginalização e reduzir as desigualdades sociais e regionais". Compreende-se, em tal contexto, faça a Constituição referência à proteção do mercado de trabalho da mulher, considerando não apenas a proibição passiva de discriminações (art. $7^{\circ}$, inciso XXX), como, ainda, a adoção de "incentivos específicos" (art. $7^{\circ}$, inciso XX). ${ }^{54}$

\footnotetext{
54 Analogamente, a Constituição portuguesa de 1976 estabelece, no art. 81: "Incumbe prioritariamente ao Estado no âmbito económico e social: a) Promover o aumento do bem-estar social e económico e da qualidade de vida das pessoas, em especial das mais desfavorecidas, no quadro de uma estratégia de desenvolvimento sustentável; b) Promover a justiça social, assegurar a igualdade de oportunidades e operar as necessárias correcções das desigualdades na distribuição da riqueza e do rendimento, nomeadamente através da política fiscal...". A Constituição da Venezuela, por sua vez, dispõe, no art. 21: “Todas las personas son iguales ante la ley; en consecuencia:... 2. La ley garantizará las condiciones juridicas y administrativas para que la igualdad ante la ley sea real y efectiva; adoptará medidas positivas a favor de personas o grupos que puedan ser
} 
Não há, por conseguinte, contraste entre o princípio constitucional da igualdade e as ações afirmativas, como reconheceu, inclusive, o Tribunal Federal da $4^{\mathrm{a}}$ Região, ao enunciar a validade do sistema de cotas, na Universidade Federal do Paraná. ${ }^{55}$

$\mathrm{Na}$ verdade, as ações afirmativas estão plenamente amparadas pela idéia de igualdade substancial, até porque só se remove a desigualdade com uma desigualdade compensatória, com o tratamento favorecido, por meio do qual se possa reequilibrar a desigualdade de fato. Não há, no caso, ofensa ao princípio da igualdade. Como explicitou o Tribunal Constitucional espanhol, "no puedan considerarse lesivas del principio de igualdad, aun cuando establezcan un trato más favorable, las medidas que tengan por objeto compensar la situación de desventaja de determinados grupos sociales y, en concreto, remediar la tradicional situación de inferioridad de la mujer en el ámbito social $y$ en el mercado de trabajo, matización que, por otra parte, viene siendo habitual en las normas internacionales más recientes sobre igualdad y no discriminación". ${ }^{56}$

Aqui bem se pode invocar, outra vez, a jurisprudência norte-americana. Teve a Suprema Corte de defrontar-se, certa feita, com o problema da aposentadoria com prazos diferenciados para homens e mulheres, cuja legitimidade se questionou, em face do princípio constitucional da igualdade. Por que o tratamento discriminatório? A Suprema Corte, em julgamento que não teve tanta repercussão como outros, assentou: "The challenged statute operated directly to compensate women for past economic discrimination. Retirement benefits under the Act are based on past earnings. But as we have recognized: "Whether from overt discrimination or from the socialization process of a male-dominated culture, the job market is inhospitable to the woman seeking any but the lowest paid jobs" Kahn v. Shevin, 416 U.S., at 353 ...Thus, allowing women, who as such have been unfairly hindered from earning as much as men, to eliminate additional lowearning years from the calculation of their retirement benefits works directly to remedy some part of the effect of past discrimination". ${ }^{57} \mathrm{E}$ a jurisprudência nacional usou argumento muito semelhante para rejeitar a tese da inconstitucionalidade da Lei n. 11.340, conforme julgado com a seguinte ementa: “Apelação - Lei Maria da Penha - Inconstitucionalidade - Inocorrência - Busca da igualdade substantiva - Coerência com o princípio da isonomia.

discriminados, marginados o vulnerables; protegerá especialmente a aquellas personas que por alguna de las condiciones antes especificadas, se encuentren en circunstancia de debilidad manifiesta y sancionará los abusos o maltratos que contra ellas se cometan".

${ }_{55}$ TRF $-4^{\text {a }}$ Reg., $3^{\text {a }}$ T., Ap. Ms n. 2005.70.00.008336-7, Rel. Juíza Maria Lúcia Luz Leiria, julg. em 25.03.2008.

${ }^{56}$ Sentença n. 19/1989, julgamento em 31.01.1989, publicada em 28.02.1989. Para outros pronunciamentos, de tribunais de diferentes países europeus, cf. FAVOREU, Louis et al. Droit des libertés fondamentales. Paris: Dalloz, 2000. $\S \S 436$ e ss., p. 343 e ss.

${ }^{57}$ Califano v. Webster (430 U.S. 313). De idêntico modo, na dissenting opinion apresentada no já citado caso Regents of Univ. of Cal. v. Bakke (438 U. S. 265), o juiz Harry Blackmun assentou: “...in order to treat some people equally we must first treat them differently". 
A ação afirmativa do Estado que busque a igualdade substantiva, após a identificação dos desníveis sócio-culturais que gere a distinção entre iguais/desiguais, não se pode tomar como inconstitucional, já que não lesa o princípio da isonomia, pelo contrário: busca torná-lo concreto, efetivo. As ações políticas destinadas ao enfrentamento da violência de gênero - deságüem ou-não em Leis - buscam a efetivação da igualdade substantiva entre homem e mulher enquanto sujeitos passivos da violência doméstica. O tratamento diferenciado que existe - e isto é fato - na Lei n. 11.340/06 entre homens e mulheres não é revelador de uma faceta discriminatória de determinada política pública, pelo contrário: revela conhecimento de que a violência tem diversidade de manifestações e, em algumas de suas formas, é subproduto de uma concepção cultural em que a submissão da mulher ao homem é um valor histórico, moral ou religioso - a origem é múltipla. Argüição de inconstitucionalidade rejeitada". 58

A afirmação adquire especial significado no campo das cotas nas universidades. É preciso ter em conta que a discriminação existente para o ingresso nas universidades decorre já da deficiência no ensino para certas pessoas. Os grupos desfavorecidos têm, em regra, um ensino de menor qualidade. Com isso, não ingressam em universidades de melhor qualidade. Em conseqüência, exercerão atividades ou funções com menor remuneração, fazendo com que a desigualdade se multiplique e, na verdade, se perpetue.

\footnotetext{
${ }_{58}^{8 J}$ TJMG, 5a Câm. Crim., Ap. Crim. n. 1.0672.07.245992-4/001(1), Rel. Des. Alexandre Victor de Carvalho, julg. em 06.11.2007 in DJMG de 01.12.2007. Em sentido oposto, todavia, decidiu o Tribunal de Justiça do Rio de Janeiro: "MANDADO DE SEGURANÇA. UERJ. SISTEMA DE COTAS PARA NEGROS, PARDOS E EGRESSOS DE ESCOLAS PÚBLICAS. LEIS ESTADUAIS n. 3708/01 e 3524/2000. Consta que o Apelante obteve o $14^{\circ}$ lugar no vestibular para o Curso de Engenharia e Produção de Petróleo do ano de 2004, sendo 20 (vinte) as vagas então disponíveis. Em razão da aplicação do sistema de reserva de vagas para negros e pardos e para alunos egressos de escolas públicas, previstos nas Leis ns. 3.708/2001 e 3.524/2000, acabou ficando fora do limite. O presente mandamus foi impetrado quando ainda vigiam as mencionadas Leis. Acontece que a Lei n. 3.708/2001 foi declarada inconstitucional pelo Egrégio Órgão Especial, na Argüição de Inconstitucionalidade 15/2005 e quanto a Lei n. 3524/2000, não mereceu apreciação pelo Órgão Especial. Sua revogação posterior não retira do Judiciário o controle difuso ou incidental acerca dos seus efeitos concretos enquanto vigia. As chamadas ações afirmativas visam dar efetividade ao princípio constitucional da igualdade no plano material. Sem dúvida que essas ações são louváveis na medida em que se almeja um Estado mais equânime, em que as oportunidades surjam igualitariamente para todos. Acontece que discriminar não é privilegiar, e o que se vê pela conjugação das leis acima apontadas é nada menos do que $70 \%$ das vagas destinadas a uma minoria. Sim, porque considerado o universo de estudantes no Estado, aqueles que estudam em escolas públicas acabam se constituindo um a minoria. E mais ainda, pois verifico que a tal lei veio atender aqueles alunos de escolas públicas tendo por pressuposto que a qualidade do ensino fornecido não estava no mesmo patamar das escolas particulares. Pois muito bem, no fundo o Estado criou um paliativo para compensar a sua ausência, a sua falha, seu desleixo na área de ensino. Não é razoável privilegiar um grupo de estudantes porque o ensino que o Estado ministra não é de boa qualidade. Aí não estaremos privilegiando, mas, quiçá, criando uma discriminação ao inverso. Ao agir assim, o Estado afrontou princípios da proporcionalidade, da razoabilidade, da igualdade, pois afrontou tanto a Constituição federal, como a Lei Federal n. 9.394/96" (TJRJ - $7^{\text {a }}$ Câm. Cív, Ap. Cív. n. 2004.001.04268, Rel. Des. Ricardo Rodrigues Cardozo, julg. em 21.11.2007).
} 
Portanto, as ações afirmativas são mesmo indispensáveis quando se pretende eliminar de fato - e não apenas de direito - a discriminação. Como assinalou em famoso voto vencido o juiz Tanaka, da Corte Internacional de Justiça: "to treat unequal matters differently according to their inequality is not only permitted but required". ${ }^{59}$ Daí ter razão E. W. Vierdag ao concluir: "it is only after compensatory unequal treatment has been accorded in compliance with the non-discrimination rule that legal equality, i.e. formal equal treatment, will also constitute material equal treatment, will produce 'genuine equality" " ${ }^{60}$ Não por outra razão a Canadian Charter of Rights and Freedoms, depois de estabelecer, na subsecção 1 , de seu art. 15 , a regra geral da igualdade, ${ }^{61}$ na subsecção seguinte estatui: “(2) Subsection (1) does not preclude any law, program or activity that has as its object the amelioration of conditions of disadvantaged individuals or groups including those that are disadvantaged because of race, national or ethnic origin, colour, religion, sex, age or mental or physical disability". ${ }^{62}$ Disse muito bem, aliás, o min. Carlos Ayres de Britto ao assinalar: "não há outro modo de concretizar o valor constitucional da igualdade senão pelo decidido combate aos fatores reais de desigualdade. O desvalor da desigualdade a proceder e justificar a imposição do valor da igualdade". ${ }^{63}$

É exatamente o que faz, embora de modo imperfeito, o art. 93, da Lei n. 8.213/91, ao impor aos empregadores a obrigação de contratação de certo número de trabalhadores deficientes. ${ }^{64}$ A disciplina legal, em tal hipótese - como em outras em que

\footnotetext{
59 South-West Africa-Case, Reports 1966, p. 248.

${ }^{60}$ VIERDAG, E. W. The concept of discrimination in international law. The Hague: Martinus Nijhoff, 1973. p. 165.
}

${ }^{61} \mathrm{O}$ texto está assim redigido: "(1) Every individual is equal before and under the law and has the right to the equal protection and equal benefit of the law without discrimination and, in particular, without discrimination based on race, national or ethnic origin, colour, religion, sex, age or mental or physical disability".

${ }^{62}$ Para indicação da admissibilidade de medidas de ação afirmativa na legislação britânica (positive discrimination), em matéria trabalhista, em favor de idosos, cf. UPEX, Robert; BENNY, Richard; HARDY, Stephen. Labor Law. Oxford: Oxford University Press, 2006. n. 4.140, p. 188.

${ }^{63}$ Item 30, do voto proferido na ADin n. 3.330-1 DF.

${ }^{64}$ Imperfeição evidente da norma indicada resulta de nela não se levarem em conta dificuldades decorrentes de impossibilidades técnicas ou de situações em que a liberdade de escolha do empregador não pode se sujeitar a parâmetros mais rigorosos, como no caso dos cargos de confiança (art. 62, inciso II, da CLT). O direito italiano, com a experiência acumulada ao longo de mais tempo de aplicação de medidas promocionais, considerou as hipóteses, ainda que em termos também algo imperfeitos e suscetíveis de aprimoramento. Dispensou, de todo modo, certas empresas do cumprimento, em relação a determinadas funções, da obrigação de admissão de deficientes, por conta de obstáculos técnicos. Trata-se do art. 13, da Lei n. 482, de 1968, em que se estatui: "Le imprese di navigazione marittima ed aerea, le ferrovie dello Stato e le imprese esercenti pubblici servizi di trasporto in concessione non sono tenute, per quanto concerne il solo personale navigante e viaggiante, all'osservanza dell'obbligo di cui al precedente articolo"). Admitiu, em relação a outras empresa, a substituição, em situações excepcionais e mediante prévia autorização administrativa, da contratação de deficientes por outras medidas promocionais. A possibilidade está no art. 13, n. 5, da mesma Lei n. 482, nos seguintes termos: "Con decreto del Ministro per il lavoro e la previdenza sociale, sentita la commissione provinciale di cui all'art. 16, le aziende private che, per le speciali condizioni della loro attività non possono occupare l'intera percentuale di invalidi prescritta, potranno essere parzialmente esonerate dall'obbligo 
se criam medidas promocionais em favor de pessoas desfavorecidas - apenas procura "riammettere al lavoro a condizione normali coloro che, per le minorazioni subite, difficilmente potrebbero affrontare la concorrenza con i lavoratori sani", como evidenciado por Valente Simi. ${ }^{65}$ Não é outro o fundamento da regra do art. $10, \S 3^{\circ}$, da Lei n. 9.504, que, ao estabelecer as normas para as eleições, dispõe: "Do número de vagas resultante das regras previstas neste artigo, cada partido ou coligação deverá reservar o mínimo de trinta por cento e o máximo de setenta por cento para candidaturas de cada sexo".

No campo trabalhista, o Tribunal Superior do Trabalho reconheceu a validade de cláusula de convenção coletiva com previsão de admissão preferencial de trabalhadores locais, normalmente preteridos em relação a trabalhadores de outras regiões, como forma de distribuir, de modo mais equânime, os resultados do desenvolvimento econômico. A ementa do julgado tem a seguinte redação: "Recurso ordinário. Ação anulatória. Recrutamento. Preferência. Mão-de-obra local. Validade. É válida a cláusula que prevê preferência na contratação de mão-de-obra local, como critério de desempate, sem consubstanciar restrição absoluta, a fim de diminuir desigualdades sociais evidentes em uma situação específica, revelando-se como verdadeira discriminação positiva, garantidora da concretização do princípio constitucional da igualdade jurídica". ${ }^{66}$

\section{Discriminação e processo}

Outra providência relevante para a eliminação da discriminação está relacionada com o Direito Processual.

Na verdade, já existem as mais importantes normas legais substanciais para combater a discriminação, ressalvada a utilização das chamadas ações afirmativas. Não são necessárias muitas outras, especialmente quando bem e corretamente interpretadas as existentes. Mas é ainda muito difícil discutir judicialmente o problema da discriminação. Por quê? Ora, por um motivo muito simples: a discriminação normalmente não se dá de modo ostensivo, declarado, manifesto. Ela é quase sempre dissimulada, disfarçada. Mostra-se "unusual to find direct evidence of racial discrimination", como registrou a

dell'assunzione, alla condizione che, in sostituzione degli invalidi, provvedano ad assumere orfani e vedove delle varie categorie. La mancata assunzione di orfani e vedove comporta la decadenza dell'esonero". Dessa forma, sem se comprometer a busca de mais igualdade substancial, deixa-se espaço para o estabelecimento de disciplina diferenciada em casos que mal se acomodam à disciplina legal de caráter geral.

${ }^{65}$ SIMI, Valente. Disposizioni di legislazione sociale particolari ad alcune categorie di lavoratori. In: Tratatto di diritto del lavoro. Padova: CEDAM, 1959. v. 3, p. 446.

${ }^{66}$ TST - SDC, Proc ROAA n. 78/2004-000-08-00, rel. Min. Kátia Magalhães Arruda, julg. em 10.04.2008 in DJU de 25.04.2008. 
House of Lords ${ }^{67}$ Isso se torna ainda mais delicado no campo do Direito do Trabalho, em que muitos atos se praticam fundados no exercício de direitos potestativos. A dispensa, por exemplo, não precisa, como regra geral, ser motivada. Não está o empregador obrigado a declinar o motivo para a rescisão do contrato de trabalho. Se pretende dispensar por motivo discriminatório, simplesmente silencia. Não indica o motivo. O mesmo vale para a admissão do trabalhador. Ninguém dirá que não admite o trabalhador por conta de seu sexo, de sua raça, de sua idade ou de outro fator discriminatório de qualquer natureza. Em conseqüência, consoante anota Jacques Le Goff, "en matière de discrimination, l'effectivité du droit butte sur l'écueil de la preuve de pratiques illicites". ${ }^{68}$ Pois bem, como isso pode ser resolvido? Só há uma forma, que envolve o segundo aspecto do combate à discriminação.

Mais uma vez o legislador português foi muito feliz. No mesmo art. 23, do Código do Trabalho, já mencionado, há uma terceira alínea, em que se lê o seguinte: "cabe a quem alegar discriminação fundamentá-la, indicando o trabalhador ou trabalhadores em relação aos quais se consideram discriminados". Em conseqüência de tal preceito, aquele que se considera discriminado por conta de sua raça, religião ou convicção ou outra circunstância, deve apenas apontar outros trabalhadores que tiveram tratamento diferenciado. Aí termina o seu encargo, que consiste em estabelecer o que os tribunais norte-americanos chamam de prima facie case. ${ }^{69}$ Prossegue o mesmo dispositivo estabelecendo que incumbe "ao empregador provar que as diferenças de condições de trabalho não assentam em nenhum dos fatores indicados no n. 1".

A regra mencionada, que encontra paralelo em outros sistemas jurídicos, ${ }^{70}$ mostra que, quando se busca realmente tratar judicialmente de casos de discriminação, é

${ }^{67}$ House of Lords [1991] IRLR 513, King v. Great Britain-China Centre apud Simon Deakin e Gillian S. Morris, Labor Law, Butterworths, London, 2003, p. 562. A Divisão Civil de Corte de Apelação da Inglaterra assinalou, a seu turno, que a produção da prova em "discrimination claims may pose great difficulties for claimants" (Igen Ltd. and Kay Wong [2005] EWCA Civ. 142).

${ }^{68}$ LE GOFF, Jacques. Droit du travai et société. Rennes: Presses Universitaires de Rennes, 2001. 1 - Les relations individuelles de travail, p. 444.

${ }^{69}$ A propósito, no campo da discriminação em matéria trabalhista, cf. McDonnell Douglas Corp. v. Green (411 U.S. 802). Os elementos do prima facie case, indicados no citado julgamento da Suprema Corte, são os seguintes: "(i) that he (o autor do pedido) belongs to a racial minority; (ii) that he applied and was qualified for a job for which the employer was seeking applicants; (iii) that, despite his qualifications, he was rejected; and (iv) that, after his rejection, the position remained open and the employer continued to seek applicants from persons of complainant's qualifications".

70 O art. 96, da Ley de Procedimiento Laboral española, por exemplo, prevê: "En aquellos procesos en que de las alegaciones de la parte actora se deduzca la existencia de indicios fundados de discriminación por razón de sexo, origen racial o étnico, religión o convicciones, discapacidad, edad u orientación sexual, corresponderá al demandado la aportación de una justificación objetiva y razonable, suficientemente probada, de las medidas adoptadas y de su proporcionalidad". E a Lei belga de 10 de maio de 2007 dispõe, em seu art. 28, $\S 1^{\circ}$ : “Lorsqu'une personne qui s'estime victime d'une discrimination, le Centre ou l'un des groupements d'intérêts invoque devant la juridiction compétente des faits qui permettent de présumer l'existence d'une 
impostergável permitir, em certos casos e preenchidas determinadas condições, a inversão do ônus da prova ${ }^{71}$ ou, como preferem outros, é preciso aliviar o ônus da prova atribuído normalmente ao autor. ${ }^{72}$ Quem estabelece a diferenciação é que fica obrigado a demonstrar a razoabilidade do critério de distinção. Deve evidenciar que a prática justifica-se por conta da natureza da atividade ou de qualquer outro fator legítimo de diferenciação. Tomese um exemplo. Não admite a empresa - imagine-se - pessoas com mais de 60 anos de idade, para utilizar exatamente o caso julgado pelo Tribunal Superior do Trabalho, a que se fez menção anteriormente. Ora, se se trata de contratação para atividade que exija alta capacidade física, o critério distintivo não será arbitrário. É, pelo contrário, legítimo. Mas - e esse é o ponto importante - deve ser ainda assim sempre ônus de quem diferencia demonstrar a razoabilidade da diferenciação.

A inversão do ônus da prova, que não se há de verificar gratuitamente, mediante mera alegação do autor, ${ }^{73}$ é um elemento essencial para o combate à discriminação. Precisa, portanto, ser tomada em conta pelo legislador, a fim de modificar o quadro hoje vigente, mediante norma clara, conhecida antecipadamente pelas partes envolvidas na relação material. ${ }^{74} \mathrm{~A}$ aplicação da regra do art. 818 , da CLT, aos pleitos relacionados com impugnação de práticas discriminatórias, dominante na jurisprudência ${ }^{75}$ cria problemas práticos evidentes, frustrando a tutela efetiva do direito à igualdade.

discrimination fondée sur l'un des critères protégés, il incombe au défendeur de prouver qu'il n'y a pas eu de discrimination". Para exame do assunto no direito holandês, cf. JACOBS, Antoine T. J. M. Labor law in the Netherlands. The Hague: Kluwer Law Internacional, 2004. n. 68, p. 60.

${ }^{71}$ Foi o que assinalou o Tribunal Constitucional espanhol, ao examinar caso envolvendo alegação de discriminação por motivo sindical: "Cuando ante un despido se invoque por el trabajador su carácter discriminatorio por vulneración del art. 17.1 del Estatuto de los Trabajadores y de derechos fundamentales comprendidos en artículos como el 14, el 16 o el 28.1 de la Constitución, de modo tal que aquella invocación genere una razonable sospecha o presunción en favor del alegato de discriminación, ha de trasladarse al empresario la prueba de la existencia de un motivo razonable de despido..."(Sentença 114/1989, de 22.06.1989).

72 GOMES, Júlio Manuel Vieira. op. cit.

73 A propósito, AROCA, Juan Montero et al. Comentarios a la ley de procedimiento laboral. Madrid: Civitas, 1993. I, p. 658.

${ }^{74}$ A modificação do ônus da prova há de ser feita pelo legislador, não podendo ficar a cargo do arbítrio judicial, sob pena de, como mostra Antonio Vallebona, comprometer a certeza do direito (VALLEBONA, Antonio. L'onere della prova nel diritto del lavoro. Padova: CEDAM, 1988. n. 1, p. 8) e, até mesmo, a garantia do contraditório, por conta da incerteza sobre o interesse no desenvolvimento da atividade instrutória.

75 "No processo originário, o ônus da prova da existência de discriminação no trabalho era da Reclamante, uma vez que referente ao fato constitutivo do seu direito à indenização por dano moral." (TST - SBDI II, ROAR n. 677.277, Rel. Min. Ives Gandra Martins Filho, julg. em 05.02.02 in DJU de 15.03.02); “...dispensa discriminatória...Ônus da prova que incumbe ao empregado (art. 818 da CLT e art. 333, I, do CPC).”(TRT - $4^{\mathrm{a}}$ Reg., 6a T., Processo n. 01520.202/97-0 (RO), Rel. Juiz João Ghisleni Filho, julg. em 04.06.98 in DJ de 29.06.98) e, ainda: "Dano moral. Ato discriminatório. Gravidez. Ônus da prova dos fatos constitutivos do direito. Regularidade de dispensa em sede de contrato de experiência. As alegações de dano moral e de atitude discriminatória em razão de gravidez, causadores da rescisão contratual, devem ser robustamente comprovadas, não deixando margem para dúvidas, sob pena de ofensa à reputação da empresa, que também merece proteção legal. Deve ser comprovada a conduta do empregador, o dano sofrido e o nexo causal entre a conduta e o dano, como fatos constitutivos do direito à reparação, na forma dos arts. 818, da CLT e 333, inciso 


\section{Conclusão}

A consolidação da democracia, sem dúvida nenhuma, é um passo que se dá no campo da eliminação da discriminação, porque todos passam a ser iguais no plano da participação política. Mas, há o reverso da medalha, que nem sempre é considerado. As sociedades divididas em castas, em grupos, em que há discriminação, são menos inclinadas a aceitar soluções democráticas e tendem a seguir caminhos autoritários. Daí porque, se a democracia contribui para uma maior igualdade, a maior igualdade também fortalece enormemente a democracia. Como lembra Carmen Lúcia Antunes Rocha, "Democracia não combina com discriminação". ${ }^{76}$ Por isso, no fundo, o combate à discriminação não é uma questão limitada. É questão muito mais ampla, que permite recuperar e atualizar os ideais que, no já distante ano de 1789, levaram à Revolução Francesa.

É preciso pensar na liberdade não mais como aquela mera faculdade de exercer determinada atividade ou como mera liberdade econômica. A liberdade é muito mais do que isso. É a efetiva possibilidade de exercício de direitos. Já a igualdade segundo postulado da Revolução Francesa - é a igualdade de oportunidades e de chances. Diferenças sempre haverá na sociedade. O que não pode haver é uma desigualdade de oportunidades. As diferenças devem resultar da diversidade de aptidão de cada um e não da dessemelhança de fortuna, de nascimento ou de outros aspectos acidentais. Com tudo isso, talvez se consiga atingir o terceiro mote da Revolução Francesa, o mais ambicioso de todos e o que está mais ausente da sociedade nos dias de hoje: a fraternidade.

São Paulo, setembro de 2008.

\section{Referências}

AROCA, Juan Montero et al. Comentarios a la ley de procedimiento laboral. Madrid: Civitas, 1993.

BARROS, Alice Monteiro de. Curso de Direito do Trabalho. São Paulo: LTr, 2005.

BERTI, Girgio. Interpretazione costituzionale. Padova: CEDAM, 1990.

I, do CPC. Não sendo realizada essa prova e verificando-se que a dispensa ocorreu em sede de contrato de experiência, não há nenhuma irregularidade que invalide o ato do empregador”. (TRT - $2^{\mathrm{a}}$ Reg., $4^{\mathrm{a}} \mathrm{T}$., RO n. 01656200631602002, Rel. Juiz Paulo Augusto Camara, Ac. n. 20080337710 in DOE de 02.05.2008).

76 ROCHA, Carmen Lúcia Antunes. Ação afirmativa. O conteúdo democrático do princípio da igualdade jurídica. Revista de Informação Legislativa, Brasília, 33, n. 131, p. 33 1999. apud BOUCINHAS FILHO, Jorge Cavalcanti. Discriminação por sobrequalificação. São Paulo, 2008. Dissertação (Mestrado) - Faculdade de Direito da Universidade de São Paulo. p. 7. 
BOUCINHAS FILHO, Jorge Cavalcanti. Discriminação por sobrequalificação. 2008. Dissertação (Mestrado) - Faculdade de Direito, Universidade de São Paulo, São Paulo.

CRISAFULLI, Vezio. Lezioni di diritto constituzioanale. Padova: CEDAM, 1974.

CURRIE, David P. The Constitution of the Federal Republic of Germany. Chicago: The University of Chicago Press, 1994.

CURCIO, Carlo. Eguaglianza (dottrine generali). In: ENCICLOPEDIA del Diritto. Varese: Giuffrè, 1965. XIV, p. 513.

DRAY, Guilherme Machado. O princípio da igualdade no Direito do Trabalho. Coimbra: Almedina, 1999.

DUGUIT, Leon. Traité de droit constitutionnel. Paris: Ancienne Librairie Fontemoing \& Cie., 1923.

FAVOREU, Louis et al. Droit des libertés fondamentales. Paris: Dalloz, 2000.

FOIGNET, René. Manuel élémentaire d'histoire du droit français. Paris: Rousseau, 1932.

FREYRE, Gilberto. Casa-Grande \& Senzala. Brasília: Editora da Universidade de Brasília, 1963.

FRIEDMANN, Wolfgang Gaston. Legal theory. 5. ed. London: Stevens \& Sons Limited, 1960.

GOMES, Júlio Manuel Vieira. Direito do trabalho. Coimbra: Coimbra Editora, 2007. v. 1.

JACOBS, Antoine T. J. M. Labor law in the Netherlands. The Hague: Kluwer Law Internacional, 2004.

JHERING, Rudolf von. L'esprit du droit romain. Paris: Marescq, 1886.

LE GOFF, Jacques. Droit du travai et société. Rennes: Presses Universitaires de Rennes, 2001.

MELLO, Celso Antônio Bandeira de. Conteúdo jurídico do princípio da igualdade. São Paulo: Malheiros, 2006.

MIRANDA, Francisco Cavalcanti Pontes de. Comentários à Constituição de 1967. Rio de Janeiro: Forense, 1987.

MIRANDA, Jorge. Manual de Direito Constitucional. Coimbra: Coimbra Editora, 1996.

MOREIRA, Teresa Alexandra Coelho. Da esfera privada do trabalho e o controlo do empregador. Coimbra: Coimbra Editora, 2004.

OLIVEIRA, Francisco Antonio de. CLT comentada. São Paulo: RT, 2000.

OLIVEIRA, Sebastião Geraldo de. Proteção jurídica à saúde do trabalhador. São Paulo: LTr, 2002.

PALLIERI, Balladore. Diritto costituzionale. Milano: Giuffrè, 1963. 
PALOMEQUE LÓPEZ, Manuel Carlos; ALVAREZ DE LA ROSA, Manuel. Derecho del trabajo: Madrid: Editorial Centro de Estúdios, 2001.

PENIDO, Laís de Oliveira (Coord.). A igualdade dos gêneros nas relações de trabalho. Brasília: Escola Superior do Ministério Público da União, 2006.

QUINTAS, Paula; QUINTAS, Helder. Código do trabalho: anotado e comentado. Coimbra: Almedina, 2004.

RAPOSO, Vera Lúcia. Os limites da igualdade: um enigma por desvendar In: PENIDO, Laís de Oliveira (Coord.). A igualdade dos gêneros nas relações de trabalho. Brasília: Escola Superior do Ministério Público da União, 2006. p. 169-171.

ROCHA, Carmen Lúcia Antunes. Ação afirmativa. O conteúdo democrático do princípio da igualdade jurídica. Revista de Informação Legislativa, Brasília, 33, n. 131, p. 33, 1999.

ROLAND, Edna Maria Santos. The economics of racism: people of african descent in Brazil. In: SEMINAR ON THE ECONOMICS OF RACISM. The International Council on Human Rights Policy, Geneva, 2001.

ROSEN, Jeffrey. The Supreme Court: the personalities and rivalries that defined America. New York: Times Books, 2006.

ROSS, Alf. Direito e justiça. São Paulo: Edipro, 2000.

SAAD, Eduardo Gabriel. CLT comentada. São Paulo: LTr, 2001.

SIMI, Valente. Disposizioni di legislazione sociale particolari ad alcune categorie di lavoratori. In: Tratatto di diritto del lavoro. Padova: CEDAM, 1959. v. 3.

TELLES, Edward. Racismo à brasileira: uma nova perspectiva sociológica. Rio de Janeiro: Relume, 2003.

UPEX, Robert; BENNY, Richard; HARDY, Stephen. Labor Law. Oxford: Oxford University Press, 2006.

VALLEBONA, Antonio. L'onere della prova nel diritto del lavoro. Padova: CEDAM, 1988.

VIERDAG, E. W. The concept of discrimination in international law. The Hague: Martinus Nijhoff, 1973. 